\title{
Changing Trends of Divorce in India: Issues \& Concerns
}

\author{
Pinto Vincent ${ }^{1} \&$ Laveena D’Mello ${ }^{2}$ \\ ${ }^{1}$ Freston Knowledge Foundation ${ }^{\circledR}$, Mangalore, Karnataka, India \\ E-mail: Vincentpinto79@gmail.com \\ ${ }^{2}$ Assistant Professor, Social Work Department, College of Social Science and Humanities, \\ Srinivas University, Mangalore, Karnataka, India \\ E-mail: lavynoronha@gmail.com
}

Type of the Paper: Research Paper.

Type of Review: Peer Reviewed.

Indexed in: OpenAIRE.

DOI: https://doi.org/10.5281/zenodo.2203824.

Google Scholar Citation: $\underline{\text { IJMTS }}$

\section{How to Cite this Paper:}

Pinto Vincent., \& D’Mello, Laveena. (2018). Changing Trends of Divorce in India: Issues \& Concerns. International Journal of Management, Technology, and Social Sciences (IJMTS), 3(2), 151-157. DOI: https://doi.org/10.5281/zenodo.2203824.

International Journal of Management, Technology, and Social Sciences (IJMTS) A Refereed International Journal of Srinivas University, India.

(C) With Authors.

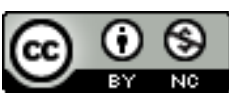

This work is licensed under a Creative Commons Attribution-Non Commercial 4.0 International License subject to proper citation to the publication source of the work.

Disclaimer: The scholarly papers as reviewed and published by the Srinivas Publications (S.P.), India are the views and opinions of their respective authors and are not the views or opinions of the SP. The SP disclaims of any harm or loss caused due to the published content to any party. 


\title{
Changing Trends of Divorce in India: Issues \& Concerns
}

\author{
Pinto Vincent ${ }^{1}$ \& Laveena D’Mello ${ }^{2}$ \\ ${ }^{1}$ Freston Knowledge Foundation ${ }^{\circledR}$, Mangalore, Karnataka, India. \\ E-mail: Vincentpinto79@gmail.com \\ ${ }^{2}$ Assistant Professor, Social Work Department, College of Social Science and Humanities, \\ Srinivas University, Mangalore, Karnataka, India. \\ E-mail: lavynoronha@gmail.com
}

\begin{abstract}
Few years ago, divorce was considered as one of the rare social phenomena in the Indian context. As the society started taking a new shape due to modernization and technological advancement, the rigid boundaries governing traditional Indian life began to replace with the new outlook as well as lifestyle. It gave a momentum when women took up employment that increased the incompatibility of gender because of the change in the position of women. Further, changing demographic contexts from rural lifestyle to city or metros,shift from extended family system to nuclear family, selection of spouse in contrary to arranged marriage are the features of changed scenario in India. In a modern society, dissolution of marriage derives from the idea that living an independent life is better than keeping marriages in terms of personal welfare. This article draws on the issues and concerns of marriages due to the changing scenario in socio-cultural life, technological outburst through social media and other forms media, influence of west, etc that has challenged the durability of the marriages in India. The aim of this study is to examine the recent trends on divorce. And the objectives are to know the socio-cultural factors that influence on the divorce rates and to suggest possible strategies for reducing or solve the problems of divorce in the family. 50 male and 50 female respondents studied in detail in this research study.
\end{abstract}

Keywords: Incompatibility, Socio-cultural factors, Divorce, Women, Marital instability, and Counsellors.

\section{INTRODUCTION :}

The family is generally regarded as a major social institution of man' social life. Family is a unit of the society created by the sacred bonding of the two through marriage. Though the family structures have changed over the years they have always retained the sacredness of the bond and the purpose of the marriage and the family. However, families today are experiencing unprecedented change and are coping with a variety of problems, both old and new. Technology accompanying industrialization and urbanization, with increased population density, frequently is identified as making daily life more complex and impersonal. Gender roles have blurred, traditional values are being questioned, and even traditional definitions and conceptualizations of 'family' have changed due to the sudden changes in the society. We witness a steady change in the value systems that influence marriage, personal development and family relationships over the last ten decades. Divorce is not looked down upon in the society today. While we know divorce was not an open discussed topic, there is greater societal acceptance of divorcees in the modern families today. Over the last 40 years an increased acceptance of divorce has influenced major changes in our attitudes on marriage as well as family life. During the 1970s, the divorce rate doubled as young folks' attitudes on fidelity, chastity and commitment became very different from those of their parents [1, 2]. 


\section{CHANGE IN THE SOCIETY :}

The change created less of an incentive to work out marital difficulties. In recent times, women of India have gone through a major cultural shift. The societal changes have created a major influence on men and women especially with industrialization and urbanization in the 20th century, and post-World War II when women entered the workplace. In response to the spurt in the economy, women are now more educated, outgoing and self-reliant.

A key feature of the Indian socio-cultural and marriage system is the strict policing of sexuality and proscription of sexuality to within marriage for women. A woman who is involved in premarital sex is considered as corrupting the purity of caste. Family and caste councils therefore have assumed the role of policing women's sexuality. This is yet another challenge on the stability of marriages. The trend on selection of spouse is changing from arranged type to love matching. Further, the use of technology in matchmaking through matrimonial websites while offering the potential to transgress traditional boundaries seems to have re-entrenched traditional values in spouse selection. The shift towards greater choice in partner selection and 'companionate' marriages in which conjugal power relationship is less hierarchical could potentially impact marriage stability. In arranged marriage stronger marital and emotional support will be provided by the family which might promote reconciliation and help to heal marital wounds. Professional rivalry between the partners is another cause of divorce. Either the man files for a divorce due to ego issues when he sees his wife more successful than him professionally [3]. Or a professionally successful woman files for a divorce when she sees that her husband's position is not at par with hers. Yet other probability for divorce is extra-marital affairs resulting in divorce. Lack of compatibility and sluggish sex life between the two are also major causes of divorce. With economic prosperity \& rising incomes, with increased ego between the partners \& professional competition, the number of divorce cases is increasing in India[4].Today most young married couples have stopped giving value to marriages \& for petty reasons, their married life fall apart. It is believed that Indians lead a more stable and contented married life. Compared to developed countries like UK, US, etc, the divorce rate in India is quite low. The US has an astounding 50\% while India has a divorce rate of $11 \%$. Britain's divorce rate soared six-fold between 1961 and 1991. But from 1991 to 2001, India has seen a rise in divorce rate, especially in the urban areas. The rate has gone up from $7.4 \%$ to $11 \%$. The question arises while looking at the position of the divorce rates that if we are truly leading a contented married life in the current society?Family as believed as an institution is a basic building block of society. Hence the fear is that Divorce weakens the base itself. Children of the divorced parents are affected to greater degrees which in turn affect the next generation. Wallenstein notes, "It's clear that we've created a new kind of society never before seen in human culture. Silently and unconsciously, we have created a culture of divorce." In a crowded courtroom on the city's outskirts, the once unthinkable is reality: dozens of couples - rich and poor, educated and barely literate - seek divorce for reasons as varied as domestic violence to a simple inability to live together. Just a decade ago, divorce was a dirty word in socially conservative India $[5,6]$. The fear of social isolation, a sense of duty to extended families - who likely arranged the marriage in the first place - and financial dependence put nearly unbearable pressure on couples to stay together. Dating among twenty something is growing popular, love matches (as opposed to arranged marriages) don't provoke the family scandals they once did and divorce is no longer out of bounds. In the 1980s, New Delhi had two courts that dealt with divorce $[7,8]$. Today there are 16. A new Indian matchmaking website Secondshaadi.com, or second marriage, now targets divorcees and widowers. A search on it throws up thousands of divorcees, most in the 25-to-35 age bracket. As the society started taking a new shape due to modernization and technological advancement, the rigid boundaries governing traditional Indian life began to replace with the new outlook as well as lifestyle. It gave 
a momentum especially when women started entering into employment that leads to the incompatibility of gender roles between men and women [9]. Further, changing demographic contexts from rural to metro life, the shift from joint family to nuclear family resulting in the individualized notion, selection of spouse, etc. have contributed to the increased unstable marriages in India. Finding the right home for a son or daughter is a matter of great family prestige. Ending a marriage is often not just about a couple going their separate ways but of two families, sometimes with business or political ties, disentangling themselves. The shame of a divorced child also makes it harder for parents to find suitable matches for their other children. But that is changing too [10, 11].

\section{GROUNDS FOR DIVORCE IN INDIA :}

In most Western nations, there are approximately 16 distinct reasons for which divorces are granted. India has different divorce laws for different religions. Almost all the religions have their own divorce laws in India which are used among themselves. There are separate laws for inter-cast or inter-religion marriages. Hindu (including Sikhs, Jains and Buddhists): Hindu Marriage Act, 1955, Muslims:Dissolution of Muslim Marriages Act, 1939, Christians:Indian Divorce Act, 1869, Parsis:The Parsi Marriage and Divorce Act, 1936, Inter-Cast or Inter-Religion: Special Marriage Act $[12,13]$.

\section{RESULTS \&DISCUSSION :}

Age of the respondents is one of the important variables in the present study. While analysing on this variable, the data shows that vast majority (70\%) of the respondents fall between the age group of 30-39 years. Majority of the divorce cases in male was seen after 35 years, however, in female majority of the divorce cases were seen before 35 years. Education is another important variable associated with divorce. In tune with the general perception that a greater number of divorces accompanies the educational status of women, it is reported that women with higher education took recourse to divorce to end marital incompatibility. Therefore, the educational status of the couples involved in divorce was inquired into. In the study vast majority of the respondents are literate. Among the respondents $4 \%$ of male and $8 \%$ of female are post graduates. The percentage of undergraduate women is almost double than that of men. The data also indicates that female respondents were better educated than male. There is much relationship between occupation and marital and family life. The study of occupations today lays so much emphasis on the individual and his/her personality that it is worthwhile to note its role in marital discord. The information concerning the occupation of the respondents explains that $42 \%$ were private employees. However, when we see the male and female respondents' separately highest frequency of male i.e. $40 \%$ were self employed and $48 \%$ female were private employees.

Nature of residence is an important aspect as far as marital adjustment and divorce are concerned. So, the nature of residence of the respondents was enquired into. The study shows $62 \%$ of the respondents belong to the rural family origin while $24 \%$ were of semi-Urban in origin and the rest $14 \%$ were of Urban in origin. The marital disruptions also related to the types of family, whether joint or nuclear. Vast majority $54 \%$ of the present study lived in nuclear families. $44 \%$ joint families and the rest $2 \%$ were belonging to extended family. However, when we see both the male and female respondents separately majority $66 \%$ of female respondents were from nuclear families and major group $58 \%$ of the male respondents were from joint families. It shows that for female who were brought up in nuclear families it is difficult to adjust in joint families and male who were adjusted to joint families most of the time have difficulty in getting along with his wife. In India free movement of the spouses is not allowed, especially in the presence of the elders even now.Numerous studies have shown that couples with children are less likely to divorce when compared to the couples without children. Divorce is more common among childless couples. Child acts as a cementing factor between the spouses. Many spouses especially females tolerate hardships and problems for the sake of children. In the absence of children, the motivation to stay together under 
stress and strain is considerably less. In this study $66 \%$ of the respondents did not have children goes to prove among other things, that childlessness and divorce have inter-relationship. In other words, childlessness facilitated easy divorce. Further in majority of the cases, the strain on the marital relationship started within the first year of marriage, and the natural love and affection starts deteriorating soon. Of course, there are a few cases of impotency and a few cases where the couple could not have children, even after staying together for quite some time. However, it is alarming to note that $34 \%$ of the respondents had children.

Today factors like education, employment, economic stability makes people to think for divorce, before going to give chance for second thought about the future. In this study $58 \%$ of the cases were initiated by women. Among male $\&$ female respondents we see separately in highest frequency of male respondents $54 \%$ said that they initiated the filing of divorce petition. However, among the female respondents highest frequency $72 \%$ of female initiated filing of divorce petition. In this study, the number of female going to the court first time for divorce is more $58 \%$ than that of the male $42 \%$. In some cases, the husband and wife together filed the divorce petition. Before 1976 an application could not be submitted jointly. In some other cases, the divorce was granted on mutual consent.The result reveals that the major cause of divorce is Unwillingness to compromise. There were $77 \%$ respondents who felt this way. Second in importance was not satisfied with each other $54 \%$ respondents. This was reacted to by poor communication of the spouses 52\%, quarrelsome disposition of spouses $48 \%$, Ego between partners $38 \%$, Interference by third parties 36\% respondents respectively. An interesting feature reveals that the financial causes and urban- rural differences as the base for divorce. Only $16 \%$ of the respondents felt that the problems of finances can lead to divorce.

In Judicial Dissolution of Marriage ground on which the court sanctions the divorce decree is an important factor. In this study $30 \%$ of the cases of divorce was granted through mutual consent. In the other $70 \%$ cases the grounds for divorce were either of the one which was specified in the Marriage Acts. $16 \%$ was of adultery, $14 \%$ was of cruelty, $10 \%$ was of desertion, $6 \%$ was of impotency, $6 \%$ was of non restitution of conjugal rights, $2 \%$ each of impotency and religious conversion and $16 \%$ of other causes. When we take the male and female cases separately in $36 \%$ of the male respondents the decree was granted on mutual consent followed by desertion $20 \%$ and adultery $14 \%$. However, in female highest frequency $24 \%$ of the cases the decree was granted on cruelty from the side of their spouse. Fonseca has pointed out that "the typical kind of joint family or in some cases extended family has been the reason for conflict and has led to dissatisfaction among many modern couples". Vast majority 54\% of the respondents of the present study lived in nuclear families. $44 \%$ were in the category of joint families and the rest $2 \%$ were belonging to extended family.

The study results show that a huge group of respondents(88\%)had a positive acceptance from their family members, friends and society. The study states that the highest number of divorced women had full sympathy from their parent and friends. Due to the strong social bondage, divorcee receives good treatment from parents \& others in India. Divorce is a personal tragedy. The gravity and implications of anguish \& pain depends on the treatment he/she receives from the society. After having received such a great defeat and failure in personal life, many people shrink from other people altogether. Some avoid people for a long time and then try to come back gradually. Reaction of the communities concerned towards the divorcees is very significant, because, it is the community which determines the status of the individual in the community.

\section{SUGGESTIONS :}

The findings of this study have great implications for social work practice, social scientists and other helping professions, particularly in the area of measures to reduce family violence and maintenance of marital stability. Having identified and discussed those 
factors in relation to divorce rates, it is pertinent to stress two general strategies for responding to the problem of divorce. They are: Strategies to prevent divorce and strengthen marriages, and Strategy to strengthen post-divorce families.In the first case, one strategy is to promote couples to participate in premarital education before getting married. The policy makers advocate strengthening marriage by reforming divorce laws to make divorce harder to obtain. And in the second case, negative consequences of divorce for children may be minimized. This is achieved when divorcing couples are encouraged to participate in 'divorce mediation'. In divorce mediation divorcing couples meet with 'a neutral third party', a 'mediator', who helps them reduce issues of property division, child custody, child support, and that encourages cooperation between the couples. Marriage or family counselling is provided by a variety of professionals, including social workers, psychologists, etc. Helped to understand behaviours and coping patterns, establish more productive communication patterns, resolve problems and support each other as family members. In almost all situations where family member is experiencing a problem or undergoing a stressful change such as sustenance abuse, family violence, rape, a serious illness, death of a family member, divorce or remarriage; family counselling can help the entire family reinforce positive changes, and address negative patterns appropriately.

\section{CONCLUSION :}

With the new strains and challenges that have emerged for the Indian family, the latter has been going through a new kind of transition. It has been wavering between traditional and Western models. The fast-changing social and family environment has thrown up new challenges particularly to the young people. The decline in harmony can also be associated with values that emphasize individualistic, materialistic and self-oriented goals over family well-being. Not only is the incidence of divorce in Indian society increasing but also the underlying causes of divorce have been assuming a new dimension or getting a new impetus, if not entirely changing. With the advancement of time, spread of education and campaigns of human rights activists, divorce has become a way to break free from the marital clutches for many women. Couples facing difficulties in equating their levels of compatibility are now filing for divorce in order to renew their life afresh. In a modern society, dissolution of marriage derives from the idea that living an independent life is better than keeping marriages in terms of personal welfare. As a decade ago, divorce was considered as one of the dirtiest social phenomena's in India is now comfortably accepted for silly reasons. Some have seen this as a sign of social and moral disruption with a potential to shatter the family institution and the foundations of society itself.

\section{REFERENCES:}

[1] Thornton, A. (1985). Changing attitude forwards separation and divorce, causes and consequences. American Journal of Sociology, 90 (4), 856-872.

[2] JuhoHarkonen (2014). Divorce: Trends, patterns, causes, consequences. Wiley Blackwell, 303-322.

[3] Morgan, S. P., Lye, D. N. \&Condran, G. A. (1988). Sons, daughters and the risk of marital disruption. American Journal of Sociology $\quad 94(1), \quad$ 110-129, DOI:10.1086/228953.

[4] D’MelloLaveena, Monteiro Meena, Govindaraju B. M. (2017). A Study on Need and Constrains of Women Entrepreneurs in Dakshina Kannada. International Journal of Case Studies in Business, IT and Education (IJCSBE), 1(2), 14-21, DOI: http://doi.org/10.5281/zenodo.833483.

[5] Goode, W. J. (1962). Marital Satisfaction and Instability. A Cross-Cultural Class Analysis of Divorce Rates. Class, Status, and Power, the Free Press, New York.

[6] Gurumukh Ram Madan (2003). Indian Social Problems, Allied Publishers Pvt. Limited, Mumbai, pp. 379-388. 
[7] Patrick C. Mc Kenry and Sharon J. Price (2000). Families \& Change, Sage publications, pp. 279-303.

[8] Joseph Hopper (2000). Marriage in a Culture of Divorce,American Journal of Sociology 106(3),848-840.

[9] D’MelloLaveena, Monteiro Meena, \& Nelson Pinto (2018). The Quality of work life and Job Satisfaction of Private Sector Employees. International Journal of Management, Technology, and Social Sciences(IJMTS), 2(2), DOI: http://dx.doi.org/10.5281/zenodo.1156448.

[10] Martin, S. P. (2006). Trends in marital dissolution by women's education in the United States. Demographic Research 15:537-560.

[11] Mastekaasa, A. (1994). Psychological wellbeing and marital dissolution. Journal of Family Issues 15(2): 208-228. DOI:10.1177/0192513X94015002004.

[12] Kant Mani Sharma (2007). Matrimonial Laws, Kamal Publishers, New Delhi, pp. $95-212$.

[13] McManus, P. A. \& DiPrete, T. A. 2001. Losers and winners: the financial consequences of separation for men. American Sociological Review 66(2): 246268. DOI:10.2307/2657417. 